\title{
The comparison of anxiety and depression levels in asthma and COPD patients
}

\author{
Aysenaz Özcan ${ }^{*}$, Adile Berna Dursun², Tugba Cicek ${ }^{1}$ \\ From 3rd WAO International Scientific Conference (WISC) 2014 \\ Rio de Janeiro, Brazil. 6-9 December 2014
}

\section{Background}

Both asthma and COPD affect mental health due to their impact on activities, sleep and social life of patients and can be resulted in anxiety and depression. The objective of the study was to determine and compare the prevalence of anxiety and depression in asthma and COPD patients.

\section{Methods}

Subjects without known psychiatric diseases were consecutively recruited from pulmonary and allergy outpatient clinics at the third level hospitals. Diagnosis of asthma and COPD was based on GINA and GOLD guideline, respectively. Depression and anxiety symptoms were evaluated using Beck Depression Inventory (BDI) and Beck Anxiety Inventory (BAI).

\section{Results}

Study group consisted of 53 patients-30 with asthma and 22 with COPD. All patients had moderate-to severe diseases. COPD group was older, had more smoking history and higher number of hospitalization than those in asthmatics. Atopy rate and education level was higher in asthmatics than those in COPD group. The mean BDI and BAI scores were 17.96 \pm 12.39 and $20.57 \pm 12.67$ in the whole group. Both group had similar degree of anxiety (21.23 \pm 11.7 vs. $19.7 \pm 14$ ), whereas BDI score was significantly higher in COPD group than that in asthmatics $(15.63 \pm 13.6$ vs. $21 \pm 10.1)(\mathrm{p}=.02)$. Age, gender, smoking history, education level, atopy status, number of emergency room admission was not correlated with scores of BDI and BAI for both group. The only effective parameter on BDI score in COPD patients was having comorbidities

${ }^{1}$ Ataturk Chest Diseases and Thoracic Surgery Training and Research Hospital, Turkey

Full list of author information is available at the end of the article

\section{Conclusions}

Both asthmatics and COPD patients regardless of their sociodemographic and clinical features have similar degree of anxiety. In addition COPD patients are more depressive than asthmatics. The study indicates that psychiatric evaluation should be a part of tailoring therapy in chronic respiratory diseases.

\section{Authors' details}

${ }^{1}$ Ataturk Chest Diseases and Thoracic Surgery Training and Research Hospital, Turkey. ${ }^{2}$ Recep Tayyip Erdogan University School of Medicine, Turkey.

Published: 8 April 2015

doi:10.1186/1939-4551-8-S1-A51

Cite this article as: Özcan et al:: The comparison of anxiety and depression levels in asthma and COPD patients. World Allergy Organization Journal 2015 8(Suppl 1):A51.

Submit your next manuscript to BioMed Central and take full advantage of:

- Convenient online submission

- Thorough peer review

- No space constraints or color figure charges

- Immediate publication on acceptance

- Inclusion in PubMed, CAS, Scopus and Google Scholar

- Research which is freely available for redistribution 